\title{
Insulin Receptor Substrate 2 Is Essential for Maturation and Survival of Photoreceptor Cells
}

\author{
Xianjin Yi, ${ }^{1 \star}$ Markus Schubert, ${ }^{1 \star}$ Neal S. Peachey, $, 2,3$ Kiyoshi Suzuma, ${ }^{4}$ Deborah J. Burks, ${ }^{1}$ Jake A. Kushner, ${ }^{1}$ \\ Izumi Suzuma, ${ }^{4}$ Christopher Cahill, ${ }^{4}$ Carrie L. Flint, ${ }^{1}$ Matthew A. Dow, ${ }^{1}$ Rebecca L. Leshan, ${ }^{1}$ George L. King ${ }^{4}$ and \\ Morris F. White ${ }^{1}$ \\ ${ }^{1}$ Howard Hughes Medical Institute, Children's Hospital Boston, Boston, Massachusetts 02115, ${ }^{2}$ Research Service, Cleveland Veterans Affairs Medical \\ Center, Cleveland, Ohio 44106, ${ }^{3}$ Cole Eye Institute, Cleveland Clinic Foundation, Cleveland, Ohio 44195, and ${ }^{4}$ Section for Vascular Cell Biology, Research \\ Division, Joslin Diabetes Center, Harvard Medical School, Boston, Massachusetts 02215
}

Insulin receptor substrates (Irs-proteins) integrate signals from the insulin and insulin-like growth factor-1 (IGF1) receptors with other processes to control cellular growth, function, and survival. Here, we show that Irs2 promoted the maturation and survival of photoreceptors in the murine retina immediately after birth. Irs2 was mainly localized to the outer plexiform layer as well as to photoreceptor inner segments. It was also seen in ganglion cells and inner plexiform layer but in smaller amounts. Compared with control littermates, Irs2 knock-out mice lose $\sim 10 \%$ of their photoreceptors 1 week after birth and up to $50 \%$ by 2 weeks of age as a result of increased apoptosis. The surviving photoreceptor cells developed short organized segments, which displayed proportionally diminished but otherwise normal electrical function. However, IGF1-stimulated Akt phosphorylation was barely detected, and cleaved/activated caspase-3 was significantly elevated in isolated retinas of Irs $2^{-/-}$mice. When diabetes was prevented, which allowed the Irs $2^{-/-}$mice to survive for 2 years, most photoreceptor cells were lost by 16 months of age. Because apoptosis is the final common pathway in photoreceptor degeneration, pharmacological strategies that increase Irs2 expression or function in photoreceptor cells could be a general treatment for blinding diseases such as retinitis pigmentosa.

Key words: Irs2; IGF1 signaling; retina; photoreceptor degeneration; apoptosis; knock-out mice

\section{Introduction}

Development of the retina, like other regions in the CNS, is regulated by transcription factors, growth factors, and neuropeptides that coordinate proliferation, differentiation, and maturation of neuroepithelial precursor cells (Frade et al., 1999; Levine et al., 2000; Kumar, 2001; Takatsuka et al., 2004). Diabetic retinopathy, the most frequent complication of diabetes and the leading cause of blindness in humans, involves vascular damage accompanied by neural apoptosis in the retina (Bronson et al., 2003). Many reports show that insulin and insulin-like growth factors (IGFs) play an important role in retinal growth and survival (Hernandez-Sanchez et al., 1995; Frade et al., 1996; Alarcon et al., 1998; Barber et al., 2001). Insulin and IGF1 receptors are found in the retina of several species, including Drosophila, chick, mice, and humans (Rodrigues et al., 1988; Bassnett and Beebe,

Received Sept. 5, 2004; revised Dec. 7, 2004; accepted Dec. 9, 2004.

This work was supported by National Institutes of Health Grant R01 DK43808 (M.F.W.) and the Medical Research Service, Department of Veterans Affairs (N.S.P.). We thank Prof. Roderick T. Bronson (Harvard Medical School, Boston, MA) for his help in histology.

*X.Y. and M.S. contributed equally to this work.

Correspondence should be addressed to Dr. Morris F. White, Howard Hughes Medical Institute, Children's Hospital Boston, Boston, MA 02115. E-mail: morris.white@childrens.harvard.edu.

M. Schubert's present address: Department of Internal Medicine II, Center for Molecular Medicine Cologne, University of Cologne, 50923 Cologne, Germany.

DOI:10.1523/JNEUROSCI.3664-04.2005

Copyright $\odot 2005$ Society for Neuroscience $\quad$ 0270-6474/05/251240-09\$15.00/0
1990; Bronson et al., 2003). IGF1 stimulates the generation of differentiated neurons in neuroepithelial cell cultures from embryonic chick neural retina (Alarcon et al., 1998). Antibodies that inhibit IGF1 signaling reduce production of differentiated retinal neurons in chick embryos (Frade et al., 1996), and antibodies that inhibit insulin signaling promote apoptosis in the neuroretina (Diaz et al., 2000). Thus, a failure of the insulin/IGF signaling cascades in photoreceptor cells themselves together with defects in the vasculature might contribute to retinopathy.

The receptors for insulin and IGF1 are tyrosine kinases that recruit and phosphorylate various proteins to generate physiological responses (White, 2003). The direct association between the insulin receptor and Dock/Nck guides axons from the retina to the developing fly brain (Song et al., 2003). The insulin receptor stimulates tyrosine phosphorylation of Chico, the fly ortholog of the mammalian insulin receptor substrates (IRS1, IRS2, IRS3, and IRS4), which promotes brain and body growth (Oldham et al., 2002). In mice, Irs1 generally controls body growth and peripheral insulin action, whereas Irs 2 integrates insulin action with body weight control, pancreatic $\beta$-cell growth and survival, and female fertility (Tamemoto et al., 1994; Withers et al., 1998, 1999; Burks et al., 2000). Disruption of the insulin receptor in neurons does not impair brain development, and retinal degeneration has not been described in these mutant mice (Bruning et al., 2000; Schubert et al., 2004), although the size of photoreceptors is reduced in insulin receptor mutant Drosophila (Brogiolo et al., 


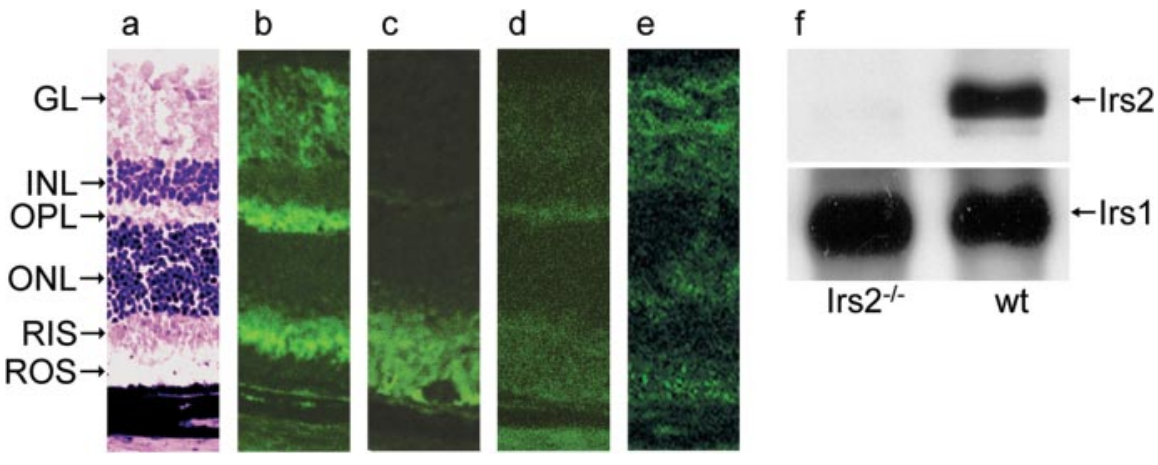

Figure 1. Irs2 expression in the retina of adult WT mice. $a$, Eyes were collected from 9-week-old mice, and frozen sections were prepared for immunofluorescent staining (original magnification, $25 \times$ ). $a$, WT retina with H\&E staining; $b$, WT retina with antibody against Irs2; $c$, WT retina with anybody against rhodopsin; $d$, WT retina without primary antibody against Irs $2 ; e, I r s 2^{-1-}$ retina with antibody against Irs2. $f$, The retinas were dissected from 9-week-old WT and $/ r s 2^{-/-}$mice, and whole retinal lysates $(50 \mu \mathrm{g})$ were separated by 7.5\% SDS-PAGE gels. Western blotting was used to detect Irs1 and Irs2. GL, Ganglion cell layer; RIS, rod inner segments; ROS, rod outer segments. a. wt
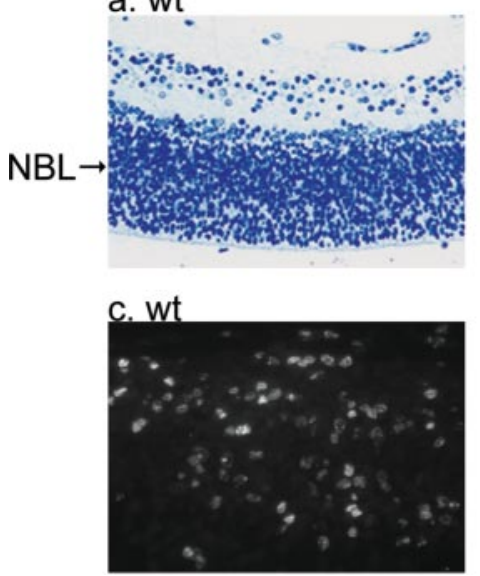
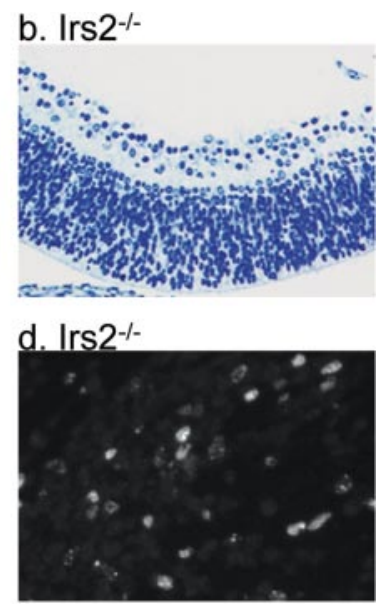

Figure 2. Proliferation of retinal precursors in WT and $/ \mathrm{rs} 2^{-/-}$retina. BrdU (100 $\mu \mathrm{g} / \mathrm{g}$ of body weight) was injected into pregnant mice at E12. Six hours later, the mice were killed, and embryos were collected. The genotype of embryos was identified by PCR. Adjacent sections were stained with $1 \%$ toludine blue $(a, b$; original magnification, $40 \times)$, or immunofluorescent staining using anti-BrdU antibody was performed ( $c$, d; original magnification, $80 \times)$. BrdUlabeled cells were counted per area using the Improvision OpenLab software (4 embryos per genotype). NBL, Neuroblast layer.

2001); however, Irs2 signaling mediates IGF1-stimulated brain growth during mouse development (Schubert et al., 2003).

Irs1 and Irs2 mediate many physiological functions of insulin and insulin-like growth factors through the direct activation of the PI 3-kinase $\rightarrow$ AKT cascade, including the inhibition of apoptosis (Alessi and Downes, 1998; Kermer et al., 2000; Barber et al., 2001; Vincent and Feldman, 2002). IGF1-stimulated PI 3-kinase protects axotomized rat retinal ganglion cells from death, whereas constitutive activation disrupts retinal morphogenesis as a result of increased survival of photoreceptors at developmental stages in which cell division has ceased (Kermer et al., 2000; Pimentel et al., 2002). Here, we show that deletion of the Irs2 gene in mice facilitates photoreceptor cell apoptosis, resulting in a 50\% loss of cells by 2 weeks of age and almost a complete loss by 16 months of age.

\section{Materials and Methods}

Animals. The generation of $\operatorname{Ir} s 1^{-/-}, \operatorname{Ir} s 2^{-/-}, \operatorname{Ir} s 2^{-/-}:: P d x 1^{\text {tg }}$, and Irs $2^{-/-}:$:rat insulin promotor-Irs $2^{\text {tg }}$ mice has been described previously (Withers et al., 1998, 1999; Kushner et al., 2002; Hennige et al., 2003). All lines were maintained on a C57BL/6 background, and wild-type (WT) littermates were used as controls. Genotyping of the animals was performed by PCR as described previously (Withers et al., 1998, 1999; Kushner et al., 2002; Hennige et al., 2003). Mice were maintained on normal $12 \mathrm{~h}$ light/dark cycle and handled in accordance with protocols approved by the local Institute Animal Care and Use Committees.

Histology. Eyeballs were either fixed in $4 \%$ paraformaldehyde for $4 \mathrm{~h}$, processed for paraffin sections, and stained with hematoxylin and eosin (H\&E) or overnight in $2.5 \%$ glutaraldehyde in $0.1 \mathrm{M}$ phosphate buffer, $\mathrm{pH} 7.4$, processed for Epon sections, and stained with 1\% toludine blue. Both paraffin and Epon sections were used for light microscopic observation. Ultrathin sections were cut from the Eponembedded samples and stained with uranyl acetate and lead citrate. These stained ultrathin sections were viewed and photographed using a Philips (Eindhoven, The Netherlands) 301 transmission electron microscope. For quantitation, H\&E-stained paraffin retinal sections from 1- and 2-week-old WT and Irs $2^{-1-}$ mice were viewed using a Zeiss (Oberkochen, Germany) Axiovert S100 microscope and video camera. The thickness of different layers of retina was measured using OpenLab software (Improvision, Lexington, MA). In each individual mouse studied, we measured a total of six retinal cross sections made through the optic nerve head. These data were then averaged, and similar results obtained from three animals of each genotype on each time point were analyzed statistically using Student's $t$ test.

5-Bromo-2-deoxyuridine labeling. 5-Bromo-2-deoxyuridine (BrdU) (Roche, Indianapolis, IN), $100 \mu \mathrm{g} / \mathrm{g}$ of body weight, was injected intraperitoneally into pregnant mice [embryonic day 12 (E12)] and 1- or 2 -week old pups. Tissues were harvested after $6 \mathrm{~h}$ and fixed in $2.5 \%$ glutaraldehyde, dehydrated, and embedded in Epon 502. Immunostaining was performed in these sections using anti-BrdU antibodies (1:1000; Roche). For quantitation, stained sections were viewed using a Zeiss Axiovert S100 microscope and video camera. Counts (of anatomical equal parts of the neuroblast layer of the retina) and analysis were done using OpenLab software (Improvision). The data were statistically analyzed using Student's $t$ test.

Immunostaining and terminal deoxynucleotidyl transferase-mediated biotinylated dUTP nick end labeling assay in retinal sections. Eyeballs were either freshly frozen in OCT for cryostat sections or fixed in 4\% paraformaldehyde for $4 \mathrm{~h}$ and processed for paraffin sections. Immunohistochemical staining in cryostat sections was used to localize Irs2 (1:200; Upstate Biotechnology, Charlottesville, VA) and rhodopsin (1:200; Santa Cruz Biotechnology, Santa Cruz, CA) in the retina. Terminal deoxynucleotidyl transferase-mediated biotinylated dUTP nick end labeling (TUNEL) assay was performed in paraffin sections using the ApopTag Peroxidase In Situ Apoptosis Detection kit (Chemicon, Temecula, CA) according to the manufacturer's instructions. The number of TUNELpositive nuclei in the inner nuclear layer (INL) or the outer nuclear layer (ONL) was counted under the microscopy. At 1 and 2 weeks of age, six sections spanning the entire retina were counted, and the data were averaged for each of three animals for each genotype. The data were statistically analyzed using Student's $t$ test.

TUNEL analysis in whole-mount retina. TUNEL analysis in wholemount retina was performed according to published methods with minor modifications (Barber et al., 1998). Briefly, the eyeballs from both WT and Irs $2^{-/-}$mice at the age of $10 \mathrm{~d}$ (four eyes of two animals from each genotype) were enucleated and fixed in $4 \%$ paraformaldehyde for $30 \mathrm{~min}$, and then retinas were dissected. Isolated retinas were flat mounted on microscope slides, dried at room temperature for $30 \mathrm{~min}$, and then incubated in a humidified box at $4^{\circ} \mathrm{C}$ overnight. On the next day, the retinas were dehydrated through graded alcohols and defatted in xylene overnight. The retinas were rehydrated and permeabilized with $0.3 \%$ Triton for $20 \mathrm{~min}$ and digested with proteinase $\mathrm{K}$ (Chemicon) for 
$30 \mathrm{~min}$ in the room temperature. TUNEL assay was performed using the ApopTag Plus Fluorescein In Situ Apoptosis Detection kit (Chemicon) according to the manufacturer's instructions.

Immunoblotting. For immunoblotting, retinas were dissected from 9-week-old Irs $2^{-1-}$ and WT mice using a dissecting microscope and then treated with human IGF1 (100 nm; R\&D Systems, Minneapolis, MN) for $20 \mathrm{~min}$. Retinas were then lysed in $50 \mathrm{~mm}$ Tris- $\mathrm{HCl}, \mathrm{pH}$ 7.4, containing $150 \mathrm{~mm} \mathrm{NaCl}, 1 \%(\mathrm{v} / \mathrm{v}) \mathrm{NP}-40,5$ mM EDTA, 5\% (v/v) glycerol, $10 \mathrm{mg} / \mathrm{ml} \mathrm{leupep-}$ tin, $10 \mathrm{mg} / \mathrm{ml}$ aprotonin, $1 \mathrm{~mm}$ phenylmethylsulfonyl fluoride, and $1 \mathrm{~mm} \mathrm{Na}_{3} \mathrm{VO}_{4}$. Protein expression was determined from whole lysates $(50 \mu \mathrm{g})$ dissolved in Laemmli buffer and resolved on 7.5\% SDS-PAGE gels. Proteins were transferred to nitrocellulose membranes, blocked with $3 \%$ dry milk solution, and incubated with the indicated antisera. Primary antibodies against Irs1, Irs2, p85, caspase-3, Akt, phospho-Akt $\left(\mathrm{Ser}^{473}\right.$ ) (Cell Signaling Technology, Beverly, MA), or IGF1-receptor (Santa Cruz Biotechnology) were detected using ECL chemiluminescence reagents and exposure to $\mathrm{x}$-ray film.

Electroretinography. After overnight dark adaptation, 10-week-old mice were anesthetized (ketamine, $80 \mathrm{mg} / \mathrm{kg}$; xylazine, $16 \mathrm{mg} / \mathrm{kg}$ ), and the pupils were dilated ( $1 \%$ tropicamide, $2.5 \%$ phenylephrine $\mathrm{HCl}, 1 \%$ cyclopentolate). The cornea was anesthetized $(0.5 \%$ proparacaine $\mathrm{HCl}$ ), and electroretinograms (ERGs) were recorded from the corneal surface using a coiled stainless steel wire; needle electrodes placed in the cheek and tail served as reference and ground leads, respectively. Responses were elicited by strobe flash stimuli, differentially amplified (bandpass, 0.5-1500 Hz), averaged, and stored using an LKC (Gaithersburg, MD) UTAS E-3000 signal averaging system. After a dark-adapted series of responses was recorded, using flash intensities that ranged from -3.6 to $2.1 \log \mathrm{cd} \mathrm{s} / \mathrm{m}^{2}$, cone ERGs were obtained to stimuli ranging from -0.1 to $1.2 \log \mathrm{cd} \mathrm{s} / \mathrm{m}^{2}$ superimposed on a steady $1.5 \mathrm{log} \mathrm{cd} / \mathrm{m}^{2}$ adapting field. The results were statistically analyzed using two-way repeated measures ANOVAs.

\section{Results}

The role of Irs 2 in maturation and survival of photoreceptor cells

Immunofluorescent staining was used to locate the Irs2 protein in the retina of normal adult mice (Fig. 1). The different layers of the retina were shown in the section stained with $\mathrm{H} \& \mathrm{E}$ (Fig. 1a). Immunofluorescent staining with an antibody against Irs2 revealed that the Irs2 protein was primarily restricted to the outer plexiform layer (OPL) and photoreceptor inner segments but was also seen in ganglion cells (GCL) and inner plexiform layer in less intensity (Fig. 1b). Irs2 was not detected in photoreceptor outer segments and the retinal pigment epithelium (Fig. 1b). The specificity of Irs2 immunostaining was confirmed by omitting the specific antibody entirely or by immunostaining $\operatorname{Irs} 2^{-/-}$retinal sections (Fig. 1d,e). By comparison, rhodopsin was localized in both inner and outer segments of photoreceptors (Fig. 1c). To confirm the expression of Irs2, retina from WT or Irs $2^{-1-}$ mice
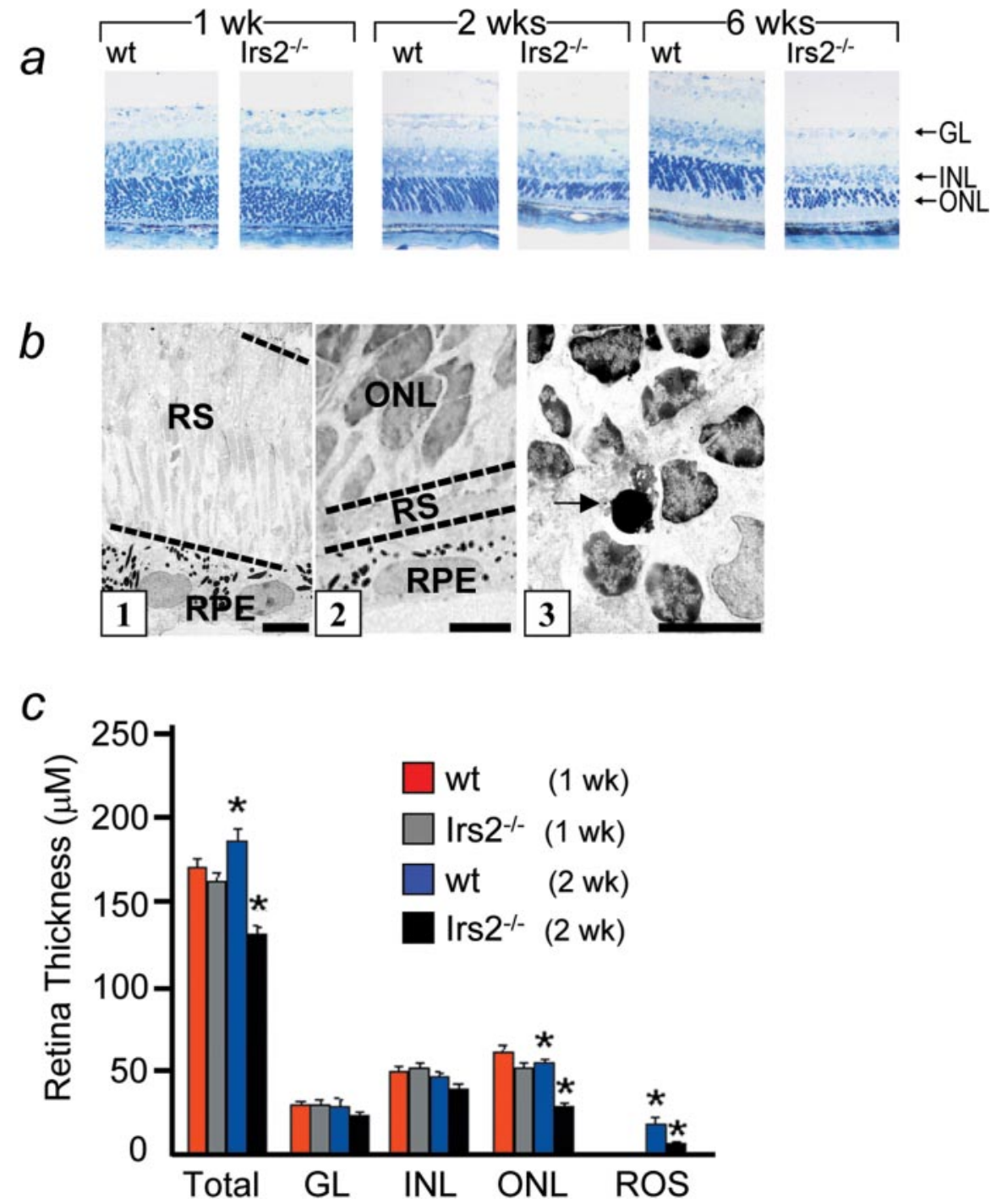

Figure 3. Morphological analysis of $/ r s 2^{-/-}$retina. Eyes of $/ r s 2^{-/-}$and WT mice at 1,2 , and 6 weeks of age were fixed in $2.5 \%$ glutaradehyde overnight and embedded in Epon 502 . Sections of $1 \mu \mathrm{m}$ thickness from central retina were stained with $1 \%$ toludine blue and used for light microscopic observation (a; original magnification, 20×). Ultrathin sections from WT and mice retina were stained with uranyl acetate and lead citrate for electron microscopic observation (b). Segments of photoreceptors in WT (b1) and Irs $2^{-/-}$(b2) and apoptotic photoreceptor in Irs $2^{-1-}$ (b3, arrow) at 2 weeks of age. Scale bars, 5 $\mu \mathrm{m}$. C, Quantitative study on the thickness of total and different layers of Irs $2^{-1-}$ mice and WT at 1 and 2 weeks of age. Six sections through optic nerve head were measured and averaged from each eye ( 6 eyes from 3 mice per genotype at each time point). GL, Ganglion cell layer; RS, rod segments; RPE, retinal pigment epithelium. ${ }^{*} p<0.01$. Error bars represent SD.

were homogenized, and the proteins were resolved by SDSPAGE. Western blotting revealed both Irs 1 and Irs2 proteins in the neuroretinae of WT mice, whereas Irs2 was absent from the neuroretinae of $I r s 2^{-/-}$mice (Fig. $1 f$ ).

To determine the effect of Irs 2 on the proliferation of retinal precursors, BrdU incorporation was determined at E12 and at 1 and 2 weeks of age. Consistent with reduced brain growth of Irs $2^{-/-}$mice (Schubert et al., 2003), the number of BrdU-labeled retinal precursors in Irs $2^{-/-}$mice at E12 was decreased by $\sim 40 \%$ (WT, 77.6 \pm 5.8; Irs $2^{-1-}, 45.4 \pm 6.2 ; p<0.01$ ) (Fig. 2). However, BrdU incorporation was nearly identical in WT and Irs $2^{-/-}$retina at 1 or 2 weeks of age (data not shown), suggesting that Irs2 signaling was not involved in the cell proliferation of postnatal retina.

To investigate the role of Irs2 in postnatal development of the retina, we examined retinal histology $3 \mathrm{~d}, 1$ week, 2 weeks, and 6 
a. wt

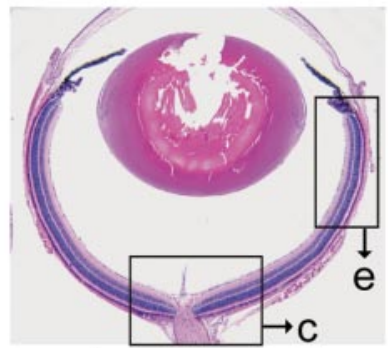

C. wt

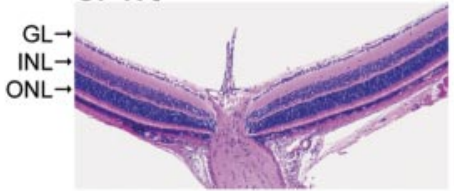

e. wt

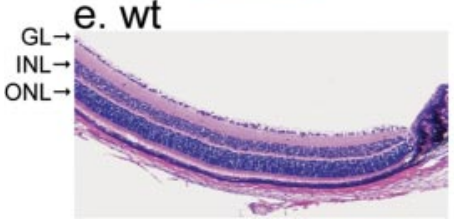

Figure 4. Morphological analysis of /rss $2^{-/-}$retina. Eyes of $/ r s 2^{-/-}$and WT mice at 2 weeks of age were fixed in $4 \%$ paraformaldehyde for $4 \mathrm{~h}$, and paraffin sections were stained with $\mathrm{H} \& \mathrm{E}$ and used for light microscopic observation (original magnification: $a, b, 4 \times$; $c-f, 20 \times)$. GL, Ganglion cell layer.

weeks of age (Fig. 3). These ages were selected to minimize the detrimental effects of hyperglycemia and hyperinsulinemia that develops after 6 weeks of age in Irs $2^{-1-}$ mice (Withers et al., 1998, 1999). At $3 \mathrm{~d}$ of age, there were no significant differences in the morphology of retina between Irs $2^{-/-}$and WT controls (data not shown). Four days later, the Irs $2^{-1-}$ retina contained all cellular and plexiform layers, but the ONL was reduced $\sim 10 \%$, and the outer segments were shorter than normal (Fig. $3 a, c)$ ). By 2 weeks of age, the $I r s 2^{-/-}$retina was 50\% thinner than WT as a result of a loss of cells in the ONL (Fig. 3a,c). Thinning of the ONL was uniform throughout the retina (Fig. 4). In contrast, the thickness of the INL or GCL were not significantly decreased in the Irs $2^{-/-}$ mice (Fig. $3 a, c)$. In addition to ONL thinning, both inner and outer segments of Irs $2^{-/}$mice were shorter than those of WT littermate controls (Fig. 3b). The thickness of the ONL in Irs $2^{-1-}$ mice changed relatively little from 2 to 6 weeks of age (Fig. $3 a$ ).

\section{Maintenance of photoreceptors during aging}

Irs $2^{-1-}$ mice normally die from extreme hyperglycemia at $\sim 15$ weeks of age as a result of $\beta$-cell death and inadequate compensatory insulin secretion (Withers et al., 1998). To examine the retina in older Irs $2^{-1-}$ mice, we restored pancreatic $\beta$-cell function in Irs $2^{-/-}$mice by transgenic expression in $\beta$-cells of the nuclear transcription factor Pdx1 ( $P d x 1^{\text {tg }}$ mice) or Irs2 (Irs $2^{\text {tg }}$ mice) (Kushner et al., 2002; Hennige et al., 2003). Previous results show that the compound $\operatorname{Irs} 2^{-1-}:: P d x 1^{\text {tg }}$ or $\operatorname{Irs} 2^{-\prime-}:: \operatorname{Ir} s 2^{\text {tg }}$ mice were insulin resistant as a result of systemic disruption of Irs2; however, these mice do not develop diabetes as a result of compensatory pancreatic $\beta$-cell function (Kushner et al., 2002; Hennige et al., 2003).

At 1,2 , and 6 weeks of the age, $\operatorname{Irs} 2^{-/-}:: P d x 1^{\text {tg }}$ mice displayed similar reductions in retinal thickness as noted in $\operatorname{Irs} 2^{-/-}$mice (data not shown). At older ages (Fig. 5), Irs ${ }^{-/-}:: P d x 1^{\text {tg }}$ mice displayed a progressive loss of photoreceptors (Fig. $5 b, c, f$ ), which was not observed in WT mice (Fig. 5a,d) or $P d x 1^{\text {tg }}$ mice (Fig. 5e). Seven $\operatorname{Irs} 2^{-\prime-}:: P d x 1^{\text {tg }}$ mice were studied at 16 months of age. The ONL was reduced to one row of nuclei in three mice or two rows of nuclei in two mice; the ONL was completely absent in two mice. At these later ages, we also noted moderate cell loss in the inner retinal layers. Because these changes were of late onset, these are likely to reflect a secondary response to photoreceptor degeneration (Marc et al., 2003). However, because Irs2 was also expressed in the inner retina, the changes of the inner retina may reflect a primary role of Irs2 in these neurons. Resolution of this issue will require the use of conditional knock-out mice. Parallel experiments using Irs $1^{-1-}$ mice, which develop glucose intolerance but not diabetes, displayed no changes in the retina (Fig. $5 h$ ). These results indicate that the Irs2 branch of the insulin/IGF signaling cascade was specifically required for survival of retinal neurons, particularly photoreceptor cells immediately after birth and for their long-term maintenance as mice age.

\section{Photoreceptor cell apoptosis in the absence of Irs2}

Apoptosis occurs during normal retinal development (Pequignot et al., 2003). To determine whether apoptosis was dysregulated in the retina of Irs2 $2^{-1-}$ mice, TUNEL was performed (Fig. 6). TUNEL staining in whole-mount retinas demonstrated that apoptosis occurred uniformly throughout the retina (Fig. $6 a, b$ ). Apoptotic cells in the different layers of the retina were localized by TUNEL staining in retinal cross sections. TUNEL-positive cells were observed equally in the GCL and in the INL of WT and Irs $2^{-1-}$ mice at 1 week of age but were barely detected in these layers by 2 weeks (Fig. $6 c, e$ ). However, the number of TUNELpositive cells was significantly increased in the ONL of Irs $2^{-/-}$ mice, particularly between 1 and 2 weeks of age, but also at later time points (Fig. $6 d, f, g$ ). Electron microscopic analysis revealed the hallmarks of apoptosis including nuclear condensation in the dying photoreceptor cells (Fig. 3b).

\section{Irs2 signaling in the retina}

Insulin/IGF1 activates the PI3-kinase $\rightarrow$ Akt cascade, which promotes cell survival by inhibiting apoptosis in a wide range of cells and tissues (Lawlor and Alessi, 2001; Vincent and Feldman, 2002). To establish a role for Irs 2 in the regulation of Akt in the retina, isolated retina were stimulated with IGF1, and Akt phosphorylation was measured by phospho-specific immunoblotting (Fig. 7). IGF1 strongly stimulated Akt phosphorylation in WT retina, whereas basal and IGF1-stimulated phosphorylation of Akt was not detected in Irs2 ${ }^{-/-}$retina (Fig. 7a). The absence of Akt phosphorylation was attributed to defective signaling, because total Akt was expressed equally in WT and Irs $2^{-\prime-}$ mice (Fig. 7a). Moreover, IGF1 receptor, Irs1, and p 85 were expressed normally in the Irs $2^{-1-}$ retina, suggesting that Irs2 was required to activate the PI3kinase $\rightarrow$ Akt cascade in the mouse retina (Fig. $7 b$ ).

Caspase- 3 exists as an inactive proenzyme that undergoes proteolysis to produce two subunits that dimerize to form the active enzyme, which plays a central role in the execution phase of cell apoptosis. Caspase- 3 is the predominant caspase involved in the cleavage of amyloid- $\beta$ 4A precursor protein, which is associated with neuronal death in Alzheimer's disease, and caspase-3 promotes apoptosis of retinal neurons (Kermer et al., 2000; Barber et al., 2001). Because the PI 3-kinase $\rightarrow$ Akt cascade strongly inhibits caspase- 3 cleavage, we examined the status of caspase- 3 in the Irs $2^{-\prime-}$ retina. The cleaved form of caspase- 3 was strongly detected by immunoblotting in the extracts of $\operatorname{Ir} s 2^{-/-}$retina, whereas it was not detected in retinal extracts from WT mice (Fig. $7 c$ ). These results suggest that the Irs2 signaling promoted pho- 
toreceptor cell survival, at least in part, by inhibiting the caspase activation cascade.

Retinal function in Irs $2^{-/-}$mice

Rhodopsin is a transmembrane protein that initiates the visual transduction cascade. Mutations in this gene are known to cause photoreceptor degeneration in retinitis pigmentosa (Dryja et al., 1991). We immunostained retinal sections from 1-, 2-, and 6-week-old WT and Irs $2^{-1-}$ mice with antibody against rhodopsin. Rhodopsin staining was reduced in the $\operatorname{Irs} 2^{-/-}$retina, consistent with the decreased number of photoreceptor cells; however, there was no difference between the location of rhodopsin in WT and $\operatorname{Irs} 2^{-/-}$retina (Fig. 8). These results show that Irs2 signaling is not involved in the synthesis or translocation of rhodopsin, which is important for normal function of photoreceptors.

To directly evaluate photoreceptor function in $\operatorname{Irs} 2^{-/-}$mice, ERGs were recorded from Irs $2^{-/-}: \because r s 2^{t g}$ mice and WT littermates using stimulus conditions that isolate rod- and cone-driven activity (Peachey and Ball, 2003) (Fig. 9). The Irs $2^{-/-}:: \operatorname{Irs} 2^{\text {tg }}$ mice were used for these experiments to avoid the physiological complication of hyperglycemia, although these mice develop progressive hyperinsulinemia (Hennige et al., 2003). Although the overall waveforms were similar, ERG amplitudes were reduced in $\operatorname{Irs} 2^{-/-}::: \operatorname{Irs} 2^{\text {tg }}$ mice (Fig. 9a). Dark-adapted ERGs, reflecting activity of the rod pathway, were significant reduced in Irs $2^{-/-}:$Irs $2^{\text {tg }}$ mice (Fig. $9 a$, top two rows of traces). Lightadapted responses, reflecting cone-driven retinal activity, were also reduced (Fig. 9a, bottom traces). The amplitude of the a-wave was significantly reduced in $\operatorname{Irs} 2^{-1-}: \because \operatorname{Irs} 2^{\text {tg }}$ mice at all flash intensities $\left(F_{(1,4)}=44.9 ; p<0.01\right)$, which was approximately proportional to the loss of photoreceptors in Irs $2^{-/-}$mice.

To determine whether Irs2 signaling affects the kinetics of phototransduction, the leading edges of the a-waves evoked by a high-intensity flash of WT and Irs $2^{-/-}:$Irs $2^{\text {tg }}$ mice were compared after normalization (Hood and Birch, 1997). When normalized, there was substantial overlap between the leading edges of the a-waves of WT and Irs $2^{-1-}:: \operatorname{Irs} 2^{\text {tg }}$ mice (Fig. $9 b$ inset), indicating that the remaining outer segments retain normal phototransduction gain (Hood and Birch, 1997). Rod-driven bwaves of Irs $2^{-/-}:$Irs $2^{\text {tg }}$ mice were also significantly reduced in amplitude (Fig. $9 c)\left(F_{(1,4)}=10.4 ; p<0.05\right)$ and delayed in implicit time (Fig. $9 d)\left(F_{(1,4)}=10.1 ; p<0.05\right)$. Although the amplitude reduction is likely to reflect a decreased input from photoreceptors, this factor alone does not account for the implicit time delays (Hood and Birch, 1992) and may reflect an additional defect in Irs $2^{-/-}$mice. The position of the a- and b-wave response functions along the intensity
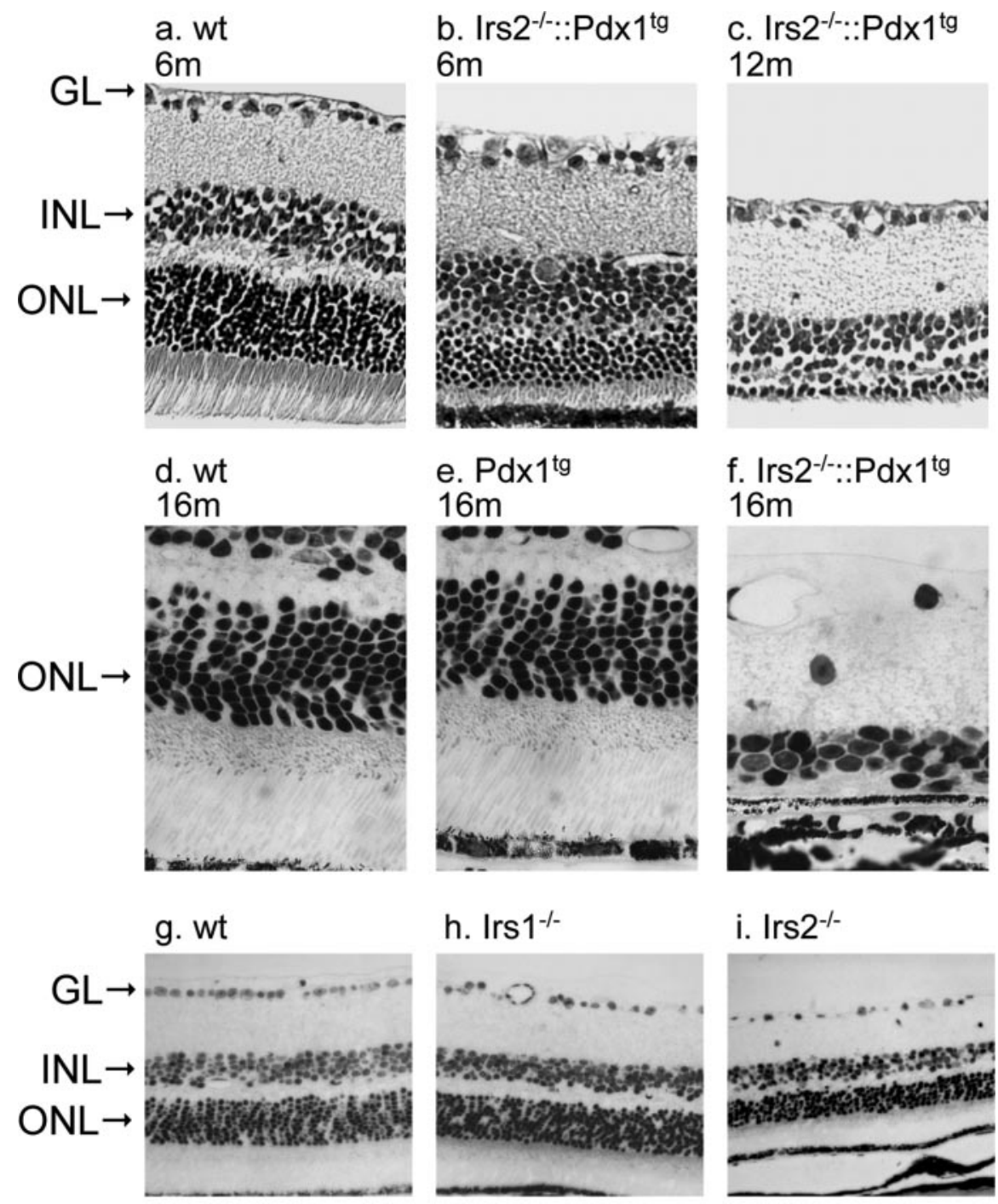

\section{i. Irs2 $2^{-1-}$}
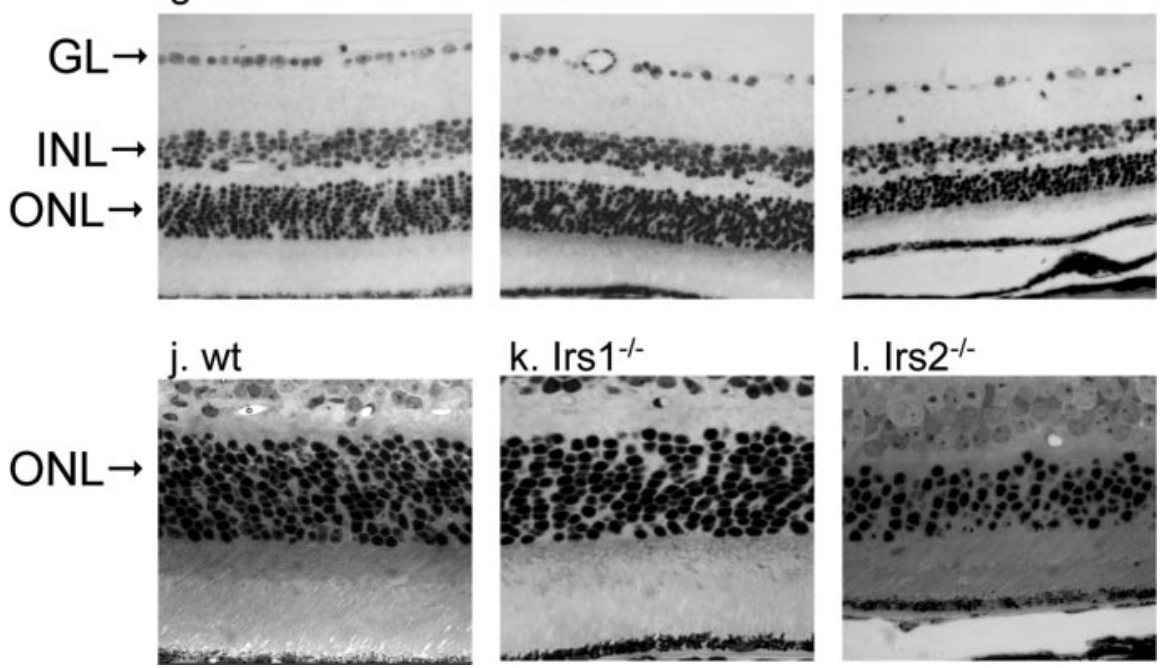

Figure 5. Morphological changes of retina in adult $/ r s 2^{-1-}$ and $/ r s 1^{-/-}$mice. Eyes were collected from older Irs $2^{-/-}:: P d x 1$ at 6,12, and 16 months of age, and cross sections were prepared for light microscopic observation ( 3 mice at 6 and 12 months, respectively; 7 mice at 16 months; $a-f) . g-l$, Retinal cross sections obtained from 9-week-old WT, Irs $1^{-/-}$, and Irs $2^{-/-}$mice (original magnification is $20 \times$ for $a, b, c, g, h, i$ and $40 \times$ for $d, e, f, j, k, l)$. GL, Ganglion cell layer. 

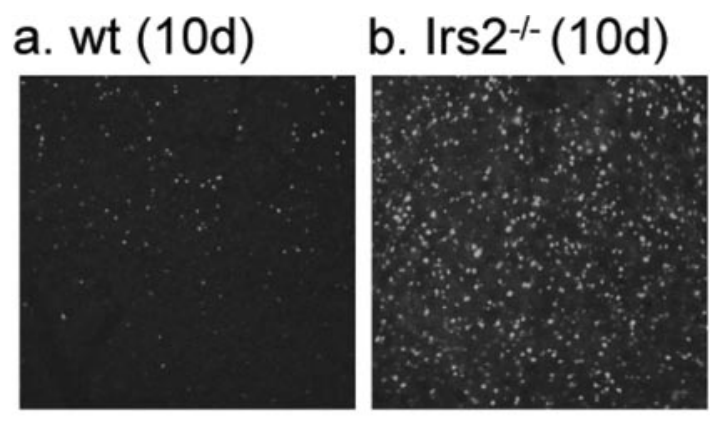

\section{c. wt (1 wk) \\ d. Irs2-/- (1 wk)}
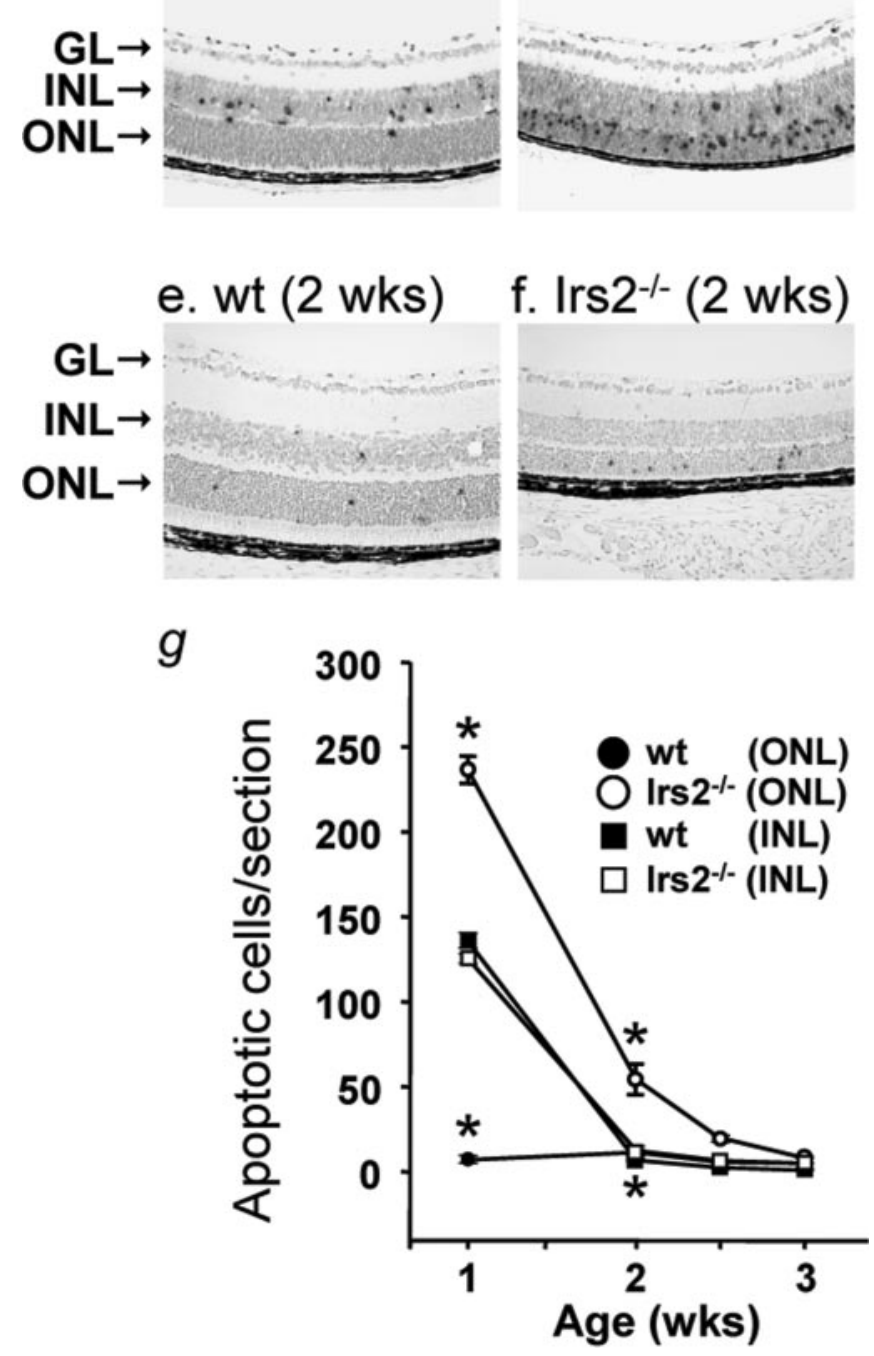

Figure 6. Apoptosis in the retina of /rs $2^{-/-}$mice. TUNEL staining in whole-mount retina from 10-d-old WT and Irs $2^{-/-}$mice using fluorescent method $(a, b)$ (original magnification, $20 \times$ ); TUNEL assay in paraffin retinal cross sections of 1 - and 2-week-old WT and Irs $2^{-/}$mice using peroxidase method $(c-f)$ (original magnification, $20 \times$ ). Positive nuclei were counted and plotted as a function of age. Six retinal cross sections were measured and averaged from each mouse; data points indicate the average $\pm S D$ of three mice $(g)$. GL, Ganglion cell layer. ${ }^{*} p<0.01$.

\section{Discussion}

Our results reveal an important but unexpected requirement for neonatal photoreceptor cell survival on the Irs2 branch of the insulin/IGF signaling cascade. During the first 3 weeks after birth,
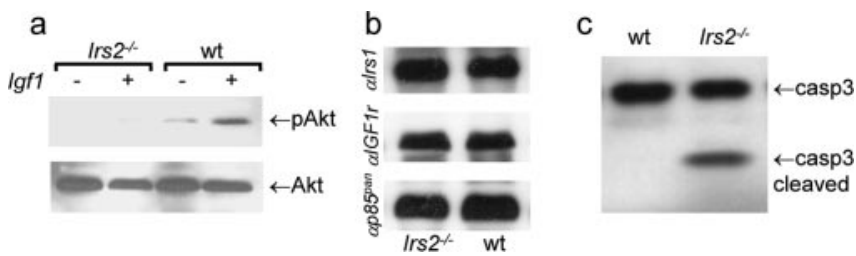

Figure 7. Akt phosphorylation and status of caspase-3 in $/ r s 2^{-1-}$ retina. The retinas were dissected from 9-week-old WT and Irs2 ${ }^{-/}$mice. The whole retinal lysates $(50 \mu \mathrm{g})$ were separated by $7.5 \%$ SDS-PAGE gels. Western blot was used to determine Irs1, IGF1r, p85, and caspase-3 (casp3) $(b, c)$. For analysis of phosphorylation of Akt, the dissected retinas were treated with or without human IGF1 in vitro (100 nm for $20 \mathrm{~min}$ ), and Western blot was used to detect Akt phosphorylation using antibody against phospho-Akt $\left(\right.$ pAkt; $\left.\mathrm{Ser}^{473}\right)($ a). Four retinas were pooled from two mice of each genotyping for each experiment, and two independent experiments were performed.
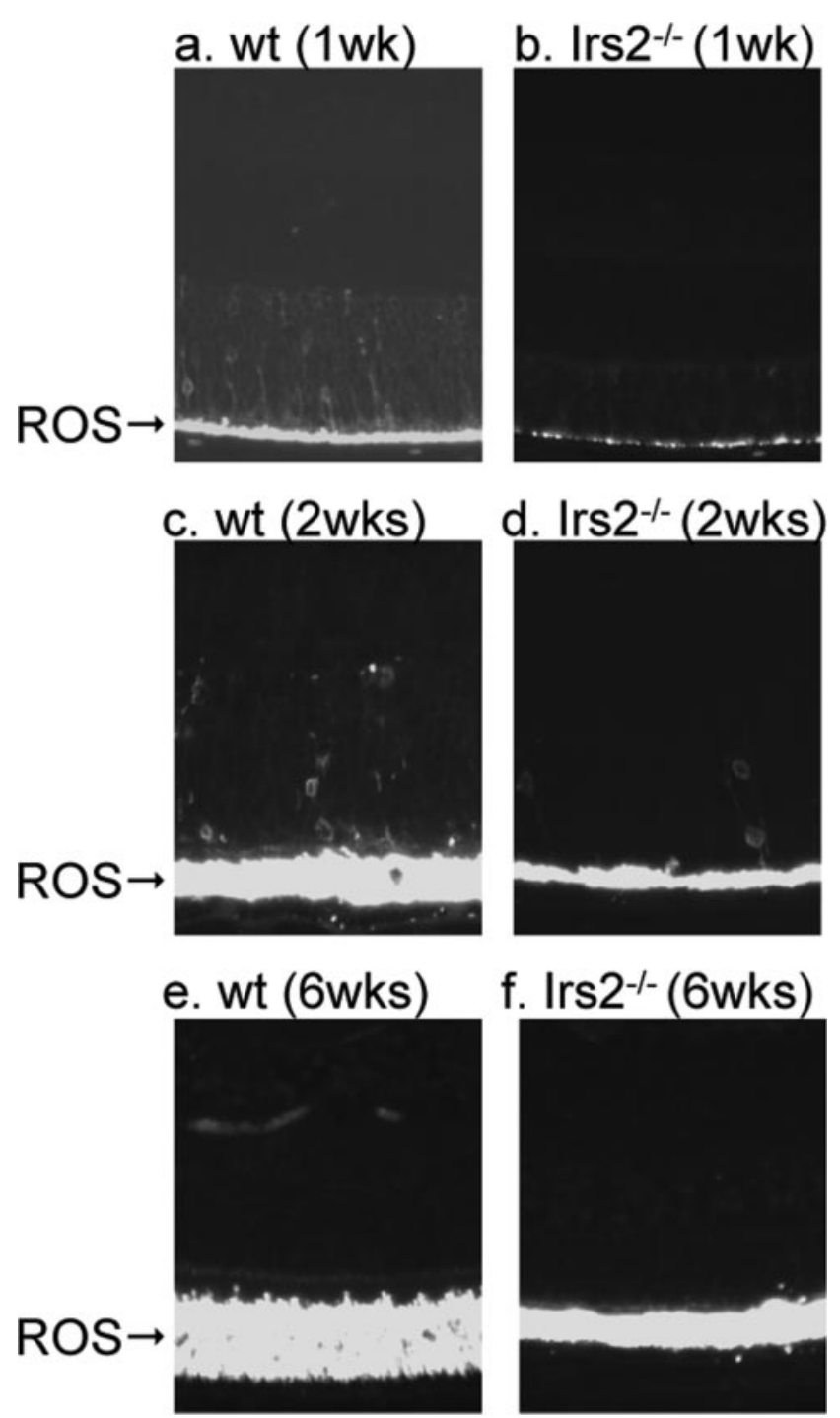

Figure 8. Immunofluorescent staining of rhodopsin. Eyeballs from 1, 2, and 6-week-old WT and $/ r s 2^{-1-}$ mice were fixed in $4 \%$ paraformaldehyde. Five-micrometer paraffin sections were made for immunofluorescent staining using anti-rhodopsin antibody. ROS, Rod outer segments (original magnification, $20 \times$ ).

a very low level of apoptosis of photoreceptor cells is seen in the retina of WT mice. In contrast, one-half of the photoreceptor cells in the Irs $2^{-1-}$ mice undergo apoptosis during this period. After this apoptotic phase, the remaining Irs $2^{-/-}$photoreceptor 
a

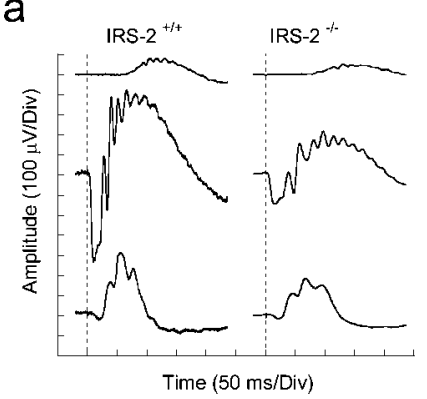

b

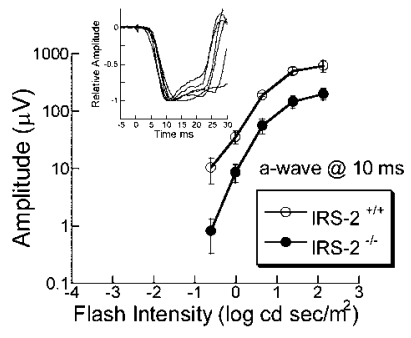

C

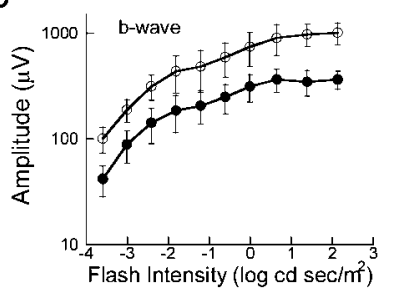

e

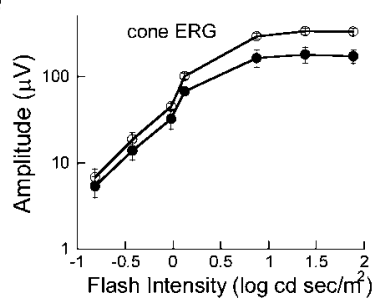

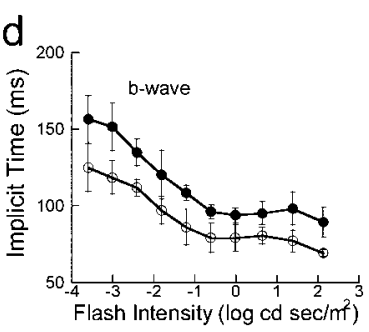

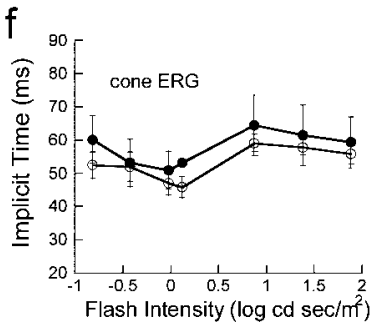

Figure 9. Electroretinography of /rs $2^{-/-}$mice. $a$, Representative ERG signals recorded from the corneal surface of /rs $2^{+/+}$(left) or /rs $2^{-/-}$(right) mice to strobe stimuli presented to the dark-adapted eye (top and middle waveforms) or superimposed on a steady rod-desensitizing adapting field (bottom waveforms). $b$, Amplitude of the dark-adapted a-wave measured at 10 $\mathrm{ms}$ after flash onset. Inset, Comparison of the leading edge of the dark-adapted ERG a-wave in three $/ r s 2^{+/+}$and three Irs $2^{-/-}$mice. c, Amplitude of the dark-adapted b-wave. $d$, Implicit time of the dark-adapted b-wave.e, Amplitude of the cone ERG.f, Implicit time of the cone ERG. Data points indicate the average $\pm S D$ of three mice.

cells survive despite the development of extreme hyperglycemia and life-threatening diabetes caused by the loss of functional pancreatic $\beta$-cells (Withers et al., 1998). When diabetes is prevented in Irs $2^{-1-}$ mice by restoring compensatory $\beta$-cell function, which includes relative hyperinsulinemia, photoreceptor cell apoptosis progresses slowly until most of the cells are lost by 16 months of age. Because phototransduction measured by ERG is relatively normal in Irs $2^{-/-}$mice, we conclude that Irs2 signaling contributes to normal vision by promoting survival of photoreceptor cells in the retina.

The important role of Irs 2 in the neonatal retina might be related, at least in part, to its relatively high expression in the OPL and photoreceptor inner segments. Irs2 is required in these cells for IGF1-stimulated activation of the PI 3-kianse $\rightarrow$ Akt cascade. Akt signaling strongly inhibits caspase cleavage cascades (Kermer et al., 2000; Barber et al., 2001; Vincent and Feldman, 2002). Activated caspase- 3 correlates with photoreceptor degeneration in various rodent models (Liu et al., 1999; Yoshizawa et al., 2002). Activated caspase- 3 accumulates in the Irs $2^{-1-}$ retina, which may explain the observed increase in photoreceptor cell apoptosis.

Irs1 is widely distributed throughout the retina, including the GCL, INL, and photoreceptor outer segments (Gosbell et al., 2000). Although both Irs1 and Irs2 exist in the retina, the morphology of the retina in $I r s 1^{-/-}$mice is normal up to two years of

age. These results suggest that Irs1 does not contribute to photoreceptor survival and are consistent with previous results showing that Irs2, but not Irs1, associates with the insulin receptor and PI 3-kinase activation in bovine photoreceptor outer segments (Rajala and Anderson, 2001; Reiter et al., 2003). The inability of Irs1 to activate the Akt and inhibit caspase-3 cleavage in the retina remains to be resolved.

Although photoreceptor apoptosis occurs in the diabetic retina (Barber et al., 1998; Park et al., 2003), it is unlikely that photoreceptor loss in Irs $2^{-/-}$mice is caused by diabetes. Normalizing glucose homeostasis in Irs $2^{-/-}$mice by transgenic expression of Pdx1 or Irs2 in the pancreatic $\beta$-cells did not restore normal retinal growth or survival. Moreover, there was no obvious photoreceptor loss in mice with a conditional knock-out of Irs2 in pancreatic $\beta$-cells that develop diabetes (data not shown) (Lin et al., 2004). Together, it appears that insulin/Igf1 signaling via Irs2 rather than negative effects of hyperglycemia is critical for photoreceptor survival.

Before birth, the proliferation of photoreceptor cell precursors is reduced in proportion to the retarded brain growth of the Irs $2^{-1}$ mice (Schubert et al., 2003). Although the brain of the Irs $2^{-1-}$ mice is $50 \%$ smaller than normal at birth, and remains small throughout life, the neonatal retina displays a nearly normal number of photoreceptor cells at birth. Furthermore, differentiation of retinal precursors is not affected by the deletion of Irs2, because all layers of the retina in Irs ${ }^{-/-}$mice form in a normal manner, except that photoreceptor outer segments never achieved a normal length. Thus, Irs2 signaling is required for early retinal precursor proliferation and photoreceptor survival after birth.

The biphasic pattern of photoreceptor degeneration that occurs in the Irs $2^{-/-}$mice is not ordinarily seen in other mouse models of retinal degeneration. In other mouse models of early onset and severe photoreceptor degeneration, virtually all the photoreceptors cells are lost by 1 month of age (Keeler, 1924; Hagstrom et al., 1999; Ramamurthy et al., 2004). The sensitivity of Irs $2^{-1-}$ photoreceptor cells to apoptosis during the postnatal period might reflect the high metabolic rate of these cells as they elaborate outer segments and become electrically active (Blanks et al., 1974; Ames et al., 1992; Bakall et al., 2003). Whether a similar requirement for Irs2 exists in human retina will be important to establish.

Rare autosomal recessive diseases reveal an association between retinal degeneration and peripheral metabolic disorders, including type 2 diabetes. Patients with Alstrom syndrome develop neurosensory hearing loss and progressive retinal degeneration accompanied by insulin resistance that progresses to type 2 diabetes (Benso et al., 2002; Iannello et al., 2004). Bardet-Biedl syndrome is characterized by many systemic disorders, including retinal dystrophy or pigmentary retinopathy, which is accompanied by abdominal obesity and type 2 diabetes (Iannello et al., 2002). Mutations in the Tubby gene family reveal a relationship between retinal function and insulin action (Ikeda et al., 2002); mutations in the mouse Tubby gene causes obesity, deafness, and retinal photoreceptor degeneration (Heckenlively et al., 1995). In addition, mutations in tubby-like protein 1 (TULP1), a member of the human Tubby gene family, are associated with autosomal recessive retinitis pigmentosa (Banerjee et al., 1998; Hagstrom et al., 1998). Moreover, disruption of the Tulp1 gene in mice causes early onset and severe photoreceptor degeneration (Hagstrom et al., 1999). Future experiments focusing on the role of Irs2 signaling in these disorders might reveal new connections between these signaling cascades. 
The development of specific treatments for every cause of retinal degeneration is complex, because mutations in over 100 genes are associated with degeneration of the human retina (Dryja, 1997; Pacione et al., 2003). Strategies to prevent retinal degeneration are under evaluation in animal models and include transplantation of retinal pigment epithelium or stem cells, gene therapy, and growth factor treatment (Milam, 1993; Ali et al., 2000; Bok et al., 2002; Kicic et al., 2003). Apoptosis appears to be the final common pathway of photoreceptor degeneration regardless of the genetic defect (Chang et al., 1993; Portera-Cailliau et al., 1994; Ren et al., 2001). Thus, strategies to inhibit photoreceptor cell apoptosis can preserve visual function, although the underlying gene defects are not corrected (Chen et al., 1996; Davidson and Steller, 1998; Nir et al., 2000). Because Irs2 expression is strongly induced by phosphorylated cAMP response elementbinding protein in $\beta$-cells and neurons, activation of this transcription factor might provide a general approach to prevent or retard photoreceptor cell degeneration (Jhala et al., 2003; Brubaker and Drucker, 2004).

\section{References}

Alarcon C, Morales AV, Pimentel B, Serna J, de Pablo F (1998) (Pro)insulin and insulin-like growth factor I complementary expression and roles in early development. Comp Biochem Physiol B Biochem Mol Biol 121:13-17.

Alessi DR, Downes CP (1998) The role of PI 3-kinease in insulin action. Biochim Biophys Acta 1436:151-164.

Ali RR, Sarra GM, Stephens C, Alwis MD, Bainbridge JW, Munro PM, Fauser S, Reichel MB, Kinnon C, Hunt DM, Bhattacharya SS, Thrasher AJ (2000) Restoration of photoreceptor ultrastructure and function in retinal degeneration slow mice by gene therapy. Nat Genet 25:306-310.

Ames III A, Li YY, Heher EC, Kimble CR (1992) Energy metabolism of rabbit retina as related to function: high cost of $\mathrm{Na}+$ transport. J Neurosci 12:840-853.

Bakall B, Marmorstein LY, Hoppe G, Peachey NS, Wadelius C, Marmorstein $\mathrm{AD}$ (2003) Expression and localization of bestrophin during normal mouse development. Invest Ophthalmol Vis Sci 44:3622-3628.

Banerjee P, Kleyn PW, Knowles JA, Lewis CA, Ross BM, Parano E, Kovats SG, Lee JJ, Penchaszadeh GK, Ott J, Jacobson SG, Gilliam TC (1998) TULP1 mutation in two extended Dominican kindreds with autosomal recessive retinitis pigmentosa. Nat Genet 18:177-179.

Barber AJ, Lieth E, Khin SA, Antonetti DA, Buchanan AG, Gardner TW (1998) Neural apoptosis in the retina during experimental and human diabetes. Early onset and effect of insulin. J Clin Invest 102:783-791.

Barber AJ, Nakamura M, Wolpert EB, Reiter CE, Seigel GM, Antonetti DA, Gardner TW (2001) Insulin rescues retinal neurons from apoptosis by a phosphatidylinositol 3-kinase/Akt-mediated mechanism that reduces the activation of caspase-3. J Biol Chem 276:32814-32821.

Bassnett S, Beebe DC (1990) Localization of insulin-like growth factor-1 binding sites in the embryonic chicken eye. Invest Ophthalmol Vis Sci 31:1637-1643.

Benso C, Hadjadj E, Conrath J, Denis D (2002) Three new cases of Alstrom syndrome. Graefes Arch Clin Exp Ophthalmol 240:622-627.

Blanks JC, Adinolfi AM, Lolley RN (1974) Synaptogenesis in the photoreceptor terminal of the mouse retina. J Comp Neurol 156:81-93.

Bok D, Yasumura D, Matthes MT, Ruiz A, Duncan JL, Chappelow AV, Zolutukhin S, Hauswirth W, Lavail MM (2002) Effects of adeno-associated virus-vectored ciliary neurotrophic factor on retinal structure and function in mice with a P216L rds/peripherin mutation. Exp Eye Res 74:719-735.

Brogiolo W, Stocker H, Ikeya T, Rintelen F, Fernandez R, Hafen E (2001) An evolutionarily conserved function of the Drosophila insulin receptor and insulin-like peptides in growth control. Curr Biol 11:213-221.

Bronson SK, Reiter CE, Gardner TW (2003) An eye on insulin. J Clin Invest 111:1817-1819.

Brubaker PL, Drucker DJ (2004) Glucagon-like peptides regulate cell proliferation and apoptosis in the pancreas, gut and central nervous system. Endocrinology 145:2653-2659.

Bruning JC, Gautam D, Burks DJ, Gillette J, Schubert M, Orban PC, Klein R,
Krone W, Muller-Wieland D, Kahn CR (2000) Role of brain insulin receptor in control of body weight and reproduction. Science 289:2122-2125.

Burks DJ, de Mora JF, Schubert M, Withers DJ, Myers MG, Towery HH, Altamuro SL, Flint CL, White MF (2000) IRS-2 pathways integrate female reproduction and energy homeostasis. Nature 407:377-382.

Chang GQ, Hao Y, Wong F (1993) Apoptosis: final common pathway of photoreceptor death in rd, rds, and rhodopsin mutant mice. Neuron 11:595-605.

Chen J, Flannery JG, Lavail MM, Steinberg RH, Xu J, Simon MI (1996) bcl-2 overexpression reduces apoptotic photoreceptor cell death in three different retinal degenerations. Proc Natl Acad Sci USA 93:7042-7047.

Davidson FF, Steller H (1998) Blocking apoptosis prevents blindness in Drosophila retinal degeneration mutants. Nature 391:587-591.

Diaz B, Serna J, de Pablo F, de la Rosa EJ (2000) In vivo regulation of cell death by embryonic (pro)insulin and the insulin receptor during early retinal neurogenesis. Development 127:1641-1649.

Dryja TP (1997) Gene-based approach to human gene-phenotype correlations. Proc Natl Acad Sci USA 94:12117-12121.

Dryja TP, Hahn LB, Cowley GS, McGee TL, Berson EL (1991) Mutation spectrum of the rhodopsin gene among patients with autosomal dominant retinitis pigmentosa. Proc Natl Acad Sci USA 88:9370-9374.

Frade JM, Marti E, Bovolenta P, Rodriguez-Pena MA, Perez-Garcia D, Rohrer H, Edgar D, Rodriguez-Tebar A (1996) Insulin-like growth factor-I stimulates neurogenesis in chick retina by regulating expression of the alpha 6 integrin subunit. Development 122:2497-2506.

Frade JM, Bovolenta P, Rodriguez-Tebar A (1999) Neurotrophins and other growth factors in the generation of retinal neurons. Microsc Res Tech 45:243-251.

Gosbell AD, Favilla I, Baxter KM, Jablonski P (2000) Insulin receptor and insulin receptor substrate-I in rat retinae. Clin Experiment Ophthalmol 28:212-215.

Hagstrom SA, North MA, Nishina PL, Berson EL, Dryja TP (1998) Recessive mutations in the gene encoding the tubby-like protein TULP1 in patients with retinitis pigmentosa. Nat Genet 18:174-176.

Hagstrom SA, Duyao M, North MA, Li T (1999) Retinal degeneration in tulp1-/- mice: vesicular accumulation in the interphotoreceptor matrix. Invest Ophthalmol Vis Sci 40:2795-2802.

Heckenlively JR, Chang B, Erway LC, Peng C, Hawes NL, Hageman GS, Roderick TH (1995) Mouse model for Usher syndrome: linkage mapping suggests homology to Usher type I reported at human chromosome 11p15. Proc Natl Acad Sci USA 92:11100-11104.

Hennige AM, Burks DJ, Ozcan U, Kulkarni RN, Ye J, Park S, Schubert M, Fisher TL, Dow MA, Leshan R, Zakaria M, Mossa-Basha M, White MF (2003) Upregulation of insulin receptor substrate-2 in pancreatic beta cells prevents diabetes. J Clin Invest 112:1521-1532.

Hernandez-Sanchez C, Lopez-Carranza A, Alarcon C, de la Rosa EJ (1995) Autocrine/panacrine role of insulin-related growth factors in neurogenesis: local expression and effects on cell proliferation and differentiation in retina. Proc Natl Acad Sci USA 92:9834-9838.

Hood DC, Birch DG (1992) A computational model of the amplitude and implicit time of the b-wave of the human ERG. Vis Neurosci 8:107-126.

Hood DC, Birch DG (1997) Assessing abnormal rod photoreceptor activity with the a-wave of the electroretinogram: application and methods. Docum Ophthal 253-267.

Iannello S, Bosco P, Cavaleri A, Camuto M, Milazzo P, Belfiore F (2002) A review of the literature of Bardet-Biedl disease and report of three cases associated with metabolic syndrome and diagnosed after the age of fifty. Obes Rev 3:123-135.

Iannello S, Bosco P, Camuto M, Cavaleri A, Milazzo P, Belfiore F (2004) A mild form of Alstrom disease associated with metabolic syndrome and very high fasting serum free fatty acids: two cases diagnosed in adult age. Am J Med Sci 327:284-288.

Ikeda A, Nishina PM, Naggert JK (2002) The tubby-like proteins, a family with roles in neuronal development and function. J Cell Sci 115:9-14.

Jhala US, Canettieri G, Screaton RA, Kulkarni RN, Krajewski S, Reed J, Walker J, Lin X, White MF, Montminy M (2003) cAMP promotes pancreatic beta-cell survival via CREB-mediated induction of IRS2. Genes Dev 17:1575-1580.

Keeler CE (1924) The inheritance of a retinal abnormality in white mice. Proc Natl Acad Sci USA 10:329-333.

Kermer P, Klocker N, Labes M, Bahr M (2000) Insulin-like growth factor-I 
protects axotomized rat retinal ganglion cells from secondary death via PI3-K-dependent Akt phosphorylation and inhibition of caspase-3 in vivo. J Neurosci 20:2-8.

Kicic A, Shen WY, Wilson AS, Constable IJ, Robertson T, Rakoczy PE (2003) Differentiation of marrow stromal cells into photoreceptors in the rat eye. J Neurosci 23:7742-7749.

Kumar JP (2001) Signalling pathways in Drosophila and vertebrate retinal development. Nat Rev Genet 2:846-857.

Kushner JA, Ye J, Schubert M, Burks DJ, Dow MA, Flint CL, Dutta S, Wright CV, Montminy MR, White MF (2002) Pdx1 restores beta cell function in Irs2 knockout mice. J Clin Invest 109:1193-1201.

Lawlor MA, Alessi DR (2001) PKB/Akt: a key mediator of cell proliferation, survival and insulin responses? J Cell Sci 114:2903-2910.

Levine EM, Fuhrmann S, Reh TA (2000) Soluble factors and the development of rod photoreceptors. Cell Mol Life Sci 57:224-234.

Lin X, Taguchi A, Park S, Kushner JA, Li F, Li Y, White MF (2004) Dysregulation of IRS2 in beta cells and brain causes obesity and diabetes. J Clin Invest 114:908-916.

Liu C, Li Y, Peng M, Laties AM, Wen R (1999) Activation of caspase-3 in the retina of transgenic rats with the rhodopsin mutation s334ter during photoreceptor degeneration. J Neurosci 19:4778-4785.

Marc RE, Jones BW, Watt CB, Strettoi E (2003) Neural remodeling in retinal degeneration. Prog Retin Eye Res 22:607-655.

Milam AH (1993) Strategies for rescue of retinal photoreceptor cells. Curr Opin Neurobiol 3:797-804.

Nir I, Kedzierski W, Chen J, Travis GH (2000) Expression of Bcl-2 protects against photoreceptor degeneration in retinal degeneration slow (rds) mice. J Neurosci 20:2150-2154.

Oldham S, Stocker H, Laffargue M, Wittwer F, Wymann M, Hafen E (2002) The Drosophila insulin/IGF receptor controls growth and size by modulating PtdInsP(3) levels. Development 129:4103-4109.

Pacione LR, Szego MJ, Ikeda S, Nishina PM, McInnes RR (2003) Progress toward understanding the genetic and biochemical mechanisms of inherited photoreceptor degenerations. Annu Rev Neurosci 26:657-700.

Park SH, Park JW, Park SJ, Kim KY, Chung JW, Chun MH, Oh SJ (2003) Apoptotic death of photoreceptors in the streptozotocin-induced diabetic rat retina. Diabetologia 46:1260-1268.

Peachey NS, Ball SL (2003) Electrophysiological analysis of visual function in mutant mice. Doc Ophthalmol 107:13-36.

Pequignot MO, Provost AC, Salle S, Taupin P, Sainton KM, Marchant D, Martinou JC, Ameisen JC, Jais JP, Abitbol M (2003) Major role of BAX in apoptosis during retinal development and in establishment of a functional postnatal retina. Dev Dyn 228:231-238.

Pimentel B, Rodriguez-Borlado L, Hernandez C, Carrera AC (2002) A role for phosphoinositide 3-kinase in the control of cell division and survival during retinal development. Dev Biol 247:295-306.

Portera-Cailliau C, Sung CH, Nathans J, Adler R (1994) Apoptotic photoreceptor cell death in mouse models of retinitis pigmentosa. Proc Natl Acad Sci USA 91:974-978.
Rajala RV, Anderson RE (2001) Interaction of the insulin receptor betasubunit with phosphatidylinositol 3-kinase in bovine ROS. Invest Ophthalmol Vis Sci 42:3110-3117.

Ramamurthy V, Niemi GA, Reh TA, Hurley JB (2004) Leber congenital amaurosis linked to AIPL1: a mouse model reveals destabilization of cGMP phosphodiesterase. Proc Natl Acad Sci USA 101:13897-13902.

Reiter CE, Sandirasegarane L, Wolpert EB, Klinger M, Simpson IA, Barber AJ, Antonetti DA, Kester M, Gardner TW (2003) Characterization of insulin signaling in rat retina in vivo and ex vivo. Am J Physiol Endocrinol Metab 285:E763-E774.

Ren JC, Stubbs Jr EB, Matthes MT, Yasumura D, Naash MI, Lavail MM, Peachey NS (2001) Retinal degeneration in the nervous mutant mouse. IV. Inner retinal changes. Exp Eye Res 72:243-252.

Rodrigues M, Waldbillig RJ, Rajagopalan S, Hackett J, LeRoith D, Chader G) (1988) Retinal insulin receptors: localization using a polyclonal antiinsulin receptor antibody. Brain Res 443:389-394.

Schubert M, Brazil DP, Burks DJ, Kushner JA, Ye J, Flint CL, Farhang-Fallah J, Dikkes P, Warot XM, Rio C, Corfas G, White MF (2003) Insulin receptor substrate-2 deficiency impairs brain growth and promotes tau phosphorylation. J Neurosci 23:7084-7092.

Schubert M, Gautam D, Surjo D, Ueki K, Baudler S, Schubert D, Kondo T, Alber J, Galldiks N, Kustermann E, Arndt S, Jacobs AH, Krone W, Kahn CR, Bruning JC (2004) Role for neuronal insulin resistance in neurodegenerative diseases. Proc Natl Acad Sci USA 101:3100-3105.

Song J, Wu L, Chen Z, Kohanski RA, Pick L (2003) Axons guided by insulin receptor in Drosophila visual system. Science 300:502-505.

Takatsuka K, Hatakeyama J, Bessho Y, Kageyama R (2004) Roles of the bHLH gene Hes1 in retinal morphogenesis. Brain Res 1004:148-155.

Tamemoto H, Kadowaki T, Tobe K, Yagi T, Sakura H, Hayakawa T, Terauchi Y, Ueki K, Kaburagi Y, Satoh S, Sekihara H, Yoshioka S, Horikoshi H, Furuta Y, Ikawa Y, Kasuga M, Yazaki Y, Aizawa S (1994) Insulin resistance and growth retardation in mice lacking insulin receptor substrate-1. Nature 372:182-186.

Vincent AM, Feldman EL (2002) Control of cell survival by IGF signaling pathways. Growth Horm IGF Res 12:193-197.

White MF (2003) Insulin signaling in health and disease. Science 302:1710-1711.

Withers DJ, Gutierrez JS, Towery H, Burks DJ, Ren JM, Previs S, Zhang Y, Bernal D, Pons S, Shulman GI, Bonner-Weir S, White MF (1998) Disruption of IRS-2 causes type 2 diabetes in mice. Nature 391:900-904.

Withers DJ, Burks DJ, Towery HH, Altamuro SL, Flint CL, White MF (1999) Irs- 2 coordinates Igf-1 receptor-mediated beta-cell development and peripheral insulin signalling. Nat Genet 23:32-40.

Yoshizawa K, Kiuchi K, Nambu H, Yang J, Senzaki H, Kiyozuka Y, Shikata N, Tsubura A (2002) Caspase-3 inhibitor transiently delays inherited retinal degeneration in $\mathrm{C} 3 \mathrm{H}$ mice carrying the rd gene. Graefes Arch Clin Exp Ophthalmol 240:214-219. 